\title{
THE LEVEL OF PHYSICAL ACTIVITY OF ADULTS LIVING IN SOUTH-EASTERN POLAND
}

\author{
Joanna Majewska' ${ }^{1 \mathrm{i}}$, \\ Gabriela Kołodziej-Lackorzyńska ${ }^{1}$, \\ Barbara Cyran-Grzebyk ${ }^{1}$, \\ Krzysztof Kołodziej ${ }^{1}$, \\ Robert Czaja ${ }^{2}$, \\ Kamil Słagaj ${ }^{2}$ \\ ${ }^{1}$ Medical College of Rzeszow University, \\ Institute of Health Science, \\ Poland \\ 2Institute of Physical Culture Studies, \\ College of Medical Sciences, \\ University of Rzeszow, \\ Poland
}

\begin{abstract}
:
Regular physical activity is associated with enhanced health and reduced risk of all-cause mortality. Despite the positive effects of physical activity on health, life has become more sedentary and the decrease in PA has affected people of all ages. The aim of our study was to assess the level of physical activity and related sociodemographic factors of adults aged 18 to 45 . Our results showed statistically significant relationships in the majority of the variables examined. Physical activity is undertaken by people of all ages, both residents of cities and rural areas. Among the surveyed inhabitants of the Podkarpackie Province, men much more often than women declare regular willingness to physical activity. The conducted own research shows that $40.90 \%$ of the studied group lead an active lifestyle, $31.06 \%$ not very active. An important issue is the use of stimulants during physical activity. The problem of using more serious stimulants, i.e. psychoactive substances in my own research, this hypothesis was not confirmed.
\end{abstract}

Keywords: physical activity, motivated factors, lifestyle, sport

i Correspondence: email joadud@gmail.com, jmajewska@ur.edu.pl 


\section{Introduction}

Regular physical activity (PA) reduces the risk of all-cause mortality by $30 \%$, reduces the risk of developing major chronic diseases such as type 2 diabetes by $42 \%$, cardiovascular disease by $35 \%$, colon cancer by $30 \%$ and increases life expectancy by up to seven years (Fredriksson et. al 2018). In addition, individuals of all ages can gain an array of psychological, social, and emotional benefits from PA (Molanorouzi et al. 2015).

However, contemporary data have demonstrated that, on average, adults spend approximately $60-70 \%$ of their waking hours involved in sedentary activities (Kantomaa et al. 2016). The effects of hypokinesia are particularly acute for people of working age, as their ability to work depends, to a large extent, on their health status and fitness and performance endurance, which are determined and sustained by physical activity (Rozek-Piechura et al. 2014). The large and increasing prevalence of physical inactivity is one of the major reasons for escalating trends of several non-communicable diseases (NCDs). Among various contributing factors to NCD-related mortality, physical inactivity alone is estimated to be responsible for $6-10 \%$ of deaths related to coronary heart disease, diabetes, and site-specific cancer (Lee IM et al. 2012). In terms of the burden on the economy, deaths due to physical inactivity contribute to $\$ 13.7$ billion in productivity losses (Ding et al. 2016).

Factors that may influence the initiation of and adherence to physical activity include age, gender, physical limitations, socioeconomic factors, psychosocial factors such as self-efficacy and social support, and environmental factors such as safety and equipment accessibility (Barber et al. 2013). With lower levels of physical activity are associated older age, female sex, lower motivation for physical activity, lower selfefficacy, poorer health status, and less previous experience in physical activity (Bauman et al. 2012).

The World Health Organization (WHO) defines physical activity as any bodily movement produced by skeletal muscles that requires energy expenditure. Physical activity refers to all movement including during leisure time, for transport to get to and from places, or as part of a person's work. Both moderate- and vigorous-intensity physical activity improve health. Adults aged 18-64 years should do at least 150-300 minutes of moderate-intensity aerobic physical activity or at least 75-150 minutes of vigorous-intensity aerobic physical activity throughout the week (WHO 2020). The WHO has targeted the reduction in the prevalence of physical inactivity as one of the goals of global action plan 2013-2020 and is working to decrease the population of people with insufficient PA worldwide (WHO 2013). With the increasing importance of PA, the USA, Canada, Australia, and several European countries develop PA guidelines at the national level to encourage people to participate in more PA (An 2017).

In Poland, the WHO Global recommendations on physical activity for health (2010) are currently used (WHO 2010). In addition, the Polish Society of Sports Medicine has developed specific recommendations on physical activity for adults and older adults, based on recommendations of the European Society of Cardiology, the American College 
of Sports Medicine and the American Heart Association (American Heart Association 2014).

Despite the importance of exercise or sport in health, the percentage of people from the EU who engage in some kind of exercise or sport has decreased in recent years, with the last reported level of inactivity in the EU being about $40 \%$. Sport is most common among residents of northern Europe. In turn, citizens of southern European countries are least physically active. In Poland only $28 \%$ of the population play sports at least once a week and $56 \%$ do not practise sports at all. The proportion of Poles who never exercise or play sports increased by 4 percentage points in the time period 2013-2017 (European Commission 2021, European Commission 2018). Globally, in 2016, the prevalence of physical inactivity among adult populations was 23.3\% (Sallis 2016).

To design evidence-based interventions to promote physical activity in a specific country, it is necessary to understand the correlates of physical activity in that particular population. Many researchers have extensively studied the level of PA of polish older adults in recent years. However, little information exists regarding PA engagement in midlife adults. This information is very important, given that midlife is a prime period for developing healthy habits to assist in later periods of the life course. Therefore, the aim of our study was to assess the level of PA and related sociodemographic factors of adults aged 18 to 45 . In order to investigate the problem in more detail, the authors presented the following research questions:

1) Is there a relationship between sex and engaged physical activity, the number of trainings per week and the duration of one training session in people aged 18-45 living in the county of Rzeszow?

2) Is there a relationship between sex and training experience, and the type of activity in people aged 18-45 living in the county of Rzeszow?

3) Is there a relationship between the type of work and engaged physical activity, number of trainings per week and duration of the one training in people aged 1845 living in the county of Rzeszow?

4) Is there a relationship between the type of work and the training experience and the type of discipline practiced in people aged 18-45 living in the Rzeszów county?

5) Is there a relationship between the place of residence and engaged physical activity and the mode of spending free time in people aged 18-45 living in the county of Rzeszow?

6) Is there a relationship between engaged/ not engaged in physical activity and use stimulants and proper diet in people aged 18-45 living in the county of Rzeszow?

7) Is there a relationship between engaged/not engaged in physical activity and factors motivated to engaged in physical activity and feel need to engage in physical activity in people aged 18-45 living in the county of Rzeszow? 


\section{Literature review}

A broad overview of Polish literature has shown that there is no scientific evidence saying about the level of physical activity in people living in areas of south-eastern Poland who are of productive age up to 45 years of age. Quite common and frequent reports of scientific research are talking about the level of physical activity in children and adolescents, pregnant women and the elderly (Zawadzka 2015, Boniecka 2018, Gablankowska 2019, Puszczałowska-Lizis 2017, Kubińska 2018). On the other hand, in the available foreign literature, there are more scientific reports in the field of physical activity, however, these studies do not cover the Podkarpackie Province and people of productive age up to 45 years of age.

The research work of Wołoszyn et al. covers the Podkarpacie region, however, it concerns physical activity of the elderly (Wołoszyn 2018). The authors emphasize the importance of physical activity for physical and mental health for people aged 60-75 (Wołoszyn 2018). In turn, Warchoł et al. in their research work describe martial arts as a form of physical activity in the Podkarpackie Province, however, the authors do not include people aged 18-45 (Warchoł et al., 2021). However, conclusions can be drawn from the research: physical activity of children and adolescents has a significant impact on mental health, shaping physical fitness and character traits of young people, which later guarantees mental, social and physical development at later stages of life (Warchol et al., 2021). Similar conclusions were made by Bidzan-Bluma and Lipowska in their research. The authors show that previously started physical activity (already in early childhood) and sports, the better develop and shape emotional, cognitive and physical functions later in life (Bidzan-Bluma, Lipowska 2018).

To sum up on the basis of a detailed review of domestic and foreign literature, it can be concluded that there are research papers on physical activity generally available for the relationships studied, but without taking into account the productive age up to 45 years of age and the region of south-eastern Poland, i.e. the Podkarpackie Voivodeship. The issue of practicing physical activity is very important, especially for people of productive age, because when we start working, we have much less time, willingness and motivation to undertake additional physical exertion, and thus physical fitness decreases, body weight increases, and emotional and social functions. Therefore, it is very important to conduct further and detailed research in this area.

\section{Material and methods}

The study was carried in the south-eastern Poland in the county of Rzeszow between October 2018 and September 2019 year excluding the holiday season (June-August 2019 years). The research was conducted in three places frequently visited by the population of Rzeszow and its vicinity, i.e. recreational areas, Rzeszow marketplace and the vicinity of cinemas and theaters. Initially, the study covered 200 people. During the preliminary analysis, 68 people were excluded from the study, because they did not meet the 
previously well-explained rules of conduct during the study or did not meet the eligibility criteria for the tests. The inclusion criteria were as follows: informed written consent to participate in the study and healthy individual (no injuries / contusions for the last 6 months) and aged 18 to 45 years. Exclusion criteria included: lack of informed written consent to participate in the survey, occurrence of an injury in the period shorter than 6 months prior to the examination giving multiple answers in the questionnaire, deleting and providing a different answer and not answering any of the questions. Finally, 132 people were qualified for the study.

The research tool was the original questionnaire consisting of 19 questions divided into three parts: the first one concerned sociodemographic data, the second concerned issues in the field of physical activity, i.e. whether the respondents engaged or not engaged physical activity, how many times a week, what is the average duration one training, what is the length of the training experience, the type of physical activity, what motivates the person to undertake physical activity and how the examined person spends his free time, and the third one, which concerned proper / improper eating and the use / non-use of stimulants. It was possible to circle a maximum of one answer in the questionnaire.

\subsection{Statistical methods}

Qualitative variables were expressed by means of quantity and indicators of the structure. The Pearson chi-square test was used to compare parameters between the studied subgroups. Statistical analysis was performed using the Statistica 13.1.

The result of the statistical test was the test probability (p), which small values indicate the statistical significance of the considered dependence. We assumed in the paper that:

1) $\mathrm{p}<0.05$ means a statistically significant relationship,

2) $\mathrm{p}<0.01$ means a statistically highly significant relationship,

3) $p<0.001$ means a statistically very highly significant relationship.

\section{Results}

The study group covered 132 respondents including 59 woman $(26.61 \pm 6.93)$ and 73 men (28.93 \pm 8.43$)$. All examined persons had the correct body weight according to BMI index. $38.99 \%$ of the study group of women lived in rural-urban areas, $35.59 \%$ lived in the city, and $24.42 \%$ of the study group of women lived in the countryside. $38.36 \%$ of the study group of men lived in the countryside, $35.62 \%$ in the city, while $26.02 \%$ of the study group of men lived in rural-urban areas. $40.90 \%$ of the study group claim that they lead an active lifestyle, $31.06 \%$ of the study group - not very active, while the smallest part of the study group claims that they lead a very active lifestyle $-28.04 \%$. Most of the study group engages in physical activity $-68.94 \%$, and the rest of it (31.06\% of the studied group) is not active. Table 1 presents the details of the study population. 
Table 1: Characteristics of the study group [average \pm ; standard deviation SD; kilograms- kg; centimeter- cm; n- number of people; one hundredth part of the whole- \%]

\begin{tabular}{|c|c|c|c|}
\hline Variable & Woman & Men & Total \\
\hline Age [ \pm ; SD]: & $26.61 \pm 6.93$ & $28.93 \pm 8.43$ & $27.89 \pm 7.85$ \\
\hline Weigh in $\mathrm{kg}[ \pm ; \mathrm{SD}]$ : & $55.42 \pm 5.96$ & $70.06 \pm 4.93$ & $63.52 \pm 9.08$ \\
\hline Heigh in $\mathrm{cm}[ \pm$; SD]: & $160.28 \pm 9.26$ & $173.68 \pm 6.40$ & $167.96 \pm 9.23$ \\
\hline $\begin{array}{l}\text { BMI [n; \%]: } \\
\text { Normal } \\
\text { Overweight } \\
\text { Obese }\end{array}$ & $\begin{array}{c}59 ; 100.00 \\
0 ; 00.00 \\
0 ; 00.00\end{array}$ & $\begin{array}{c}73 ; 100.00 \\
0 ; 00.00 \\
0 ; 00.00\end{array}$ & $\begin{array}{c}132.00 ; 100.00 \\
0 ; 00.00 \\
0 ; 00.00\end{array}$ \\
\hline $\begin{array}{l}\text { Place of living [n; \%]: } \\
\text { City } \\
\text { Rural area } \\
\text { Rural-urban area }\end{array}$ & $\begin{array}{l}21 ; 35.59 \\
15 ; 24.42 \\
23 ; 38.99\end{array}$ & $\begin{array}{l}26 ; 35.62 \\
28 ; 38.36 \\
19 ; 26.02\end{array}$ & $\begin{array}{l}47 ; 35.60 \\
43 ; 32.58 \\
42 ; 31.82\end{array}$ \\
\hline $\begin{array}{l}\text { Education [n; \%]: } \\
\text { Basic } \\
\text { Medium } \\
\text { Vocational } \\
\text { High }\end{array}$ & $\begin{array}{c}0 ; 00.00 \\
0 ; 00.00 \\
20 ; 33.89 \\
39 ; 66.11\end{array}$ & $\begin{array}{c}0 ; 00.00 \\
0 ; 00.00 \\
47 ; 64.38 \\
26 ; 35.62\end{array}$ & $\begin{array}{c}0 ; 00.00 \\
0 ; 00.00 \\
67 ; 50.76 \\
65 ; 49.24\end{array}$ \\
\hline $\begin{array}{l}\text { Lifestyle [n; \%]: } \\
\text { Not very active } \\
\text { Active } \\
\text { Very active }\end{array}$ & $\begin{array}{l}17 ; 28.81 \\
23 ; 38.98 \\
19 ; 32.21\end{array}$ & $\begin{array}{l}24 ; 32.89 \\
31 ; 42.46 \\
18 ; 24.65\end{array}$ & $\begin{array}{l}41 ; 31.06 \\
54 ; 40.90 \\
37 ; 28.04\end{array}$ \\
\hline $\begin{array}{l}\text { Type of work [n; \%]: } \\
\text { Unemployed } \\
\text { Sedentary mode } \\
\text { Standing mode }\end{array}$ & $\begin{array}{c}39 ; 66.11 \\
4 ; 6.77 \\
16 ; 27.12\end{array}$ & $\begin{array}{l}17 ; 23.28 \\
21 ; 28.77 \\
35 ; 47.95\end{array}$ & $\begin{array}{l}56 ; 42.42 \\
25 ; 18.94 \\
51 ; 38.64\end{array}$ \\
\hline $\begin{array}{l}\text { Undertaking physical } \\
\text { activity [n; \%] } \\
\text { Yes } \\
\text { No }\end{array}$ & $\begin{array}{l}42 ; 71.18 \\
17 ; 28.82\end{array}$ & $\begin{array}{l}49 ; 67.12 \\
24 ; 32.88\end{array}$ & $\begin{array}{l}91 ; 68.94 \\
41 ; 31.06\end{array}$ \\
\hline
\end{tabular}

The data from Table 2 suggest statistically significant dependence between sex and the number of trainings per week and duration of one training session. There was no statistically significant difference between sex and engaged/not engaged in physical activity in people aged 18-45 living in the county of Rzeszow.

Table 2: Relationship between sex and engaged physical activity, the number of trainings per week and the duration of one training session in people aged 18-45 living in the county of Rzeszow

\begin{tabular}{|l|c|c|c|}
\hline Variable & Woman & Men & $\begin{array}{c}\text { Pearson's chi } \\
\text { square p-value }\end{array}$ \\
\hline Engaged/not engaged in physical activity [n; \%] & & & \\
Yes & $42 ; 71.18$ & $49 ; 67.12$ & \\
No & $17 ; 28.82$ & $24 ; 32.88$ &, $251565 ; \mathrm{p}=0.61$ \\
\hline Numbers of trainings per week [n; \%] & & & \\
No training & $17 ; 28.81$ & $24 ; 32.88$ & \\
$1 \mathrm{x}$ & $30 ; 50.85$ & $13 ; 17.80$ & \\
\hline
\end{tabular}




\begin{tabular}{|l|c|c|c|}
\hline \hline $2-3 \mathrm{x}$ & $12 ; 20.34$ & $14 ; 13.17$ & $\mathbf{2 8 , 9 1 0 3 ;} \mathbf{p = 0 . 0 0}$ \\
$4 \mathrm{x}$ & $0 ; 00.00$ & $22 ; 30.13$ & \\
$5 \mathrm{x}$ and more & $0 ; 00.00$ & $0 ; 00.00$ & \\
\hline Duration of one training session [n; \%]: & & & \\
No training & $17 ; 28.81$ & $24 ; 32.88$ & \\
1 hour & $30 ; 50.85$ & $23 ; 31.50$ & \\
2 hours & $12 ; 20.34$ & $26 ; 35.61$ & $\mathbf{5 , 8 5 8 6 0 ;} \mathbf{p}=\mathbf{0 . 0 5}$ \\
3 hours & $0 ; 00.00$ & $0 ; 00.00$ & \\
More than 4 hours & $0 ; 00.00$ & $0 ; 00.00$ & \\
\hline
\end{tabular}

On the basis of the research included in the Table 3, it has been stated that there is a statistically significant relationship between sex and training experience and type of physical activity in people aged 18-45 living in the county of Rzeszow. Table 3 shows that $67.12 \%$ of men engage in a type of physical activity which is the gym (fitness, zumba, step etc.) and the same type of physical activity applies to $50.85 \%$ women. The longest training experience belongs to $36.98 \%$ men and the shortest to $52.54 \%$ woman.

Table 3: Relationship between sex and training experience and type of physical activity in people aged 18-45 living in the county of Rzeszow

\begin{tabular}{|l|c|c|c|}
\hline Variable & Woman & Men & $\begin{array}{c}\text { Pearson's chi } \\
\text { square } \mathbf{p} \text {-value }\end{array}$ \\
\hline Training experience [n; \%]: & & & \\
No training & $17 ; 28.81$ & $24 ; 32.88$ & \\
Less than year & $31 ; 52.54$ & $10 ; 13.70$ & \\
1-2 years & $11 ; 18.64$ & $12 ; 16.44$ & $\mathbf{3 7 , 9 3 6 6 ;} \mathbf{p = 0 . 0 0}$ \\
3-4 years & $0 ; 00.00$ & $27 ; 36.98$ & \\
More than year & $0 ; 00.00$ & $0 ; 00.00$ & \\
\hline Type of engaged/not engaged of physical activity & & & \\
[n; $\%$ ]: & & & \\
Not engaged & $17 ; 28.81$ & $24 ; 32.88$ & \\
Gym (fitness, zumba, step etc.) & $30 ; 50.85$ & $49 ; 67.12$ & \\
Team sport games (soccer, handball, volleyball etc.) & $12 ; 20.34$ & $0 ; 00.00$ & $\mathbf{1 6 , 4 6 5 1 ;} \mathbf{p = 0 . 0 0}$ \\
Swim & $0 ; 00.00$ & $0 ; 00.00$ & \\
Dance & $0 ; 00.00$ & $0 ; 00.00$ & \\
\hline
\end{tabular}

We found statistically significant relationships between the type of work and type of engaged/ not engaged of physical activity, numbers of training in a week and duration of the one training in people aged 18-45 living in the county of Rzeszow. Our research indicated that $84.31 \%$ people with standing mode of work were engaged in physical activity. The smallest group of the study group who were engaged in physical activity were people with sedentary mode work (52\%). Our research indicated that more than half respondents $(62.50 \%)$ who were unemployed were engaged in physical activity. In terms of the number of trainings per week, the largest group were people who were not employed. On the other hand, people with the highest number of training sessions per week $(2-4 x)$ were people with standing mode work. Detailed information are provided in Table 4. 
Table 4: Relationship between the type of work and engaged/ not engaged of physical activity, numbers of training in a week and duration of the one training in people aged 18-45 living in the county of Rzeszow

\begin{tabular}{|c|c|c|c|c|}
\hline Variable & Unemployed & $\begin{array}{l}\text { Sedentary } \\
\text { mode }\end{array}$ & $\begin{array}{l}\text { Standing } \\
\text { mode }\end{array}$ & $\begin{array}{l}\text { Pearson's chi } \\
\text { square p-value }\end{array}$ \\
\hline $\begin{array}{l}\text { Engaged/not engaged } \\
\text { in physical activity [n; \%]: } \\
\text { Yes } \\
\text { No }\end{array}$ & $\begin{array}{l}35 ; 62.50 \\
21 ; 37.50\end{array}$ & $\begin{array}{l}13 ; 52.00 \\
12 ; 48.00\end{array}$ & $\begin{array}{c}43 ; 84.31 \\
8 ; 15.69\end{array}$ & 10,$0642 ; p=0.00$ \\
\hline $\begin{array}{l}\text { Numbers of trainings } \\
\text { per week }[\mathrm{n} ; \%] \text { : } \\
\text { No training } \\
1 \mathrm{x} \\
2-3 \mathrm{x} \\
4 \mathrm{x} \\
5 \mathrm{x} \text { and more }\end{array}$ & $\begin{array}{c}21 ; 37.50 \\
25 ; 44.64 \\
4 ; 7.14 \\
6 ; 10.72 \\
0 ; 00.00\end{array}$ & $\begin{array}{c}12 ; 48.00 \\
1 ; 4.00 \\
9 ; 36.00 \\
3 ; 12.00 \\
0 ; 00.00\end{array}$ & $\begin{array}{c}8 ; 15.69 \\
17 ; 33.33 \\
13 ; 25.49 \\
13 ; 25.49 \\
0 ; 00.00\end{array}$ & 28,$3400 ; p=0.00$ \\
\hline $\begin{array}{l}\text { Duration of one training } \\
\text { session [n; } \% \text { ]: } \\
\text { No training } \\
1 \text { hour } \\
2 \text { hours } \\
3 \text { hours } \\
\text { More than } 4 \text { hours } \\
\end{array}$ & $\begin{array}{c}21 ; 37.50 \\
29 ; 51.79 \\
6 ; 10.72 \\
0 ; 00.00 \\
0 ; 00.00 \\
\end{array}$ & $\begin{array}{c}12 ; 48.00 \\
4 ; 16.00 \\
9 ; 36.00 \\
0 ; 00.00 \\
0 ; 00.00 \\
\end{array}$ & $\begin{array}{c}8 ; 15.69 \\
20 ; 39.22 \\
23 ; 45.09 \\
0 ; 00.00 \\
0 ; 00.00 \\
\end{array}$ & 23,$9878 ; p=0.00$ \\
\hline
\end{tabular}

On the basis of the research included in the table 5, it has been stated that there is a statistically significant relationship between people who are unemployed, sedentary mode work and standing mode work and training experience. Table 5 shows that the longest training experience had people who were working in standing mode- $27.45 \%$. The largest group of untrained people were people with sedentary mode work- $48 \%$. $84.31 \%$ of a study group are people who declare practicing a type of physical activity which is the gym, and they were works in a standing mode. The data contained in the table 5 are statistically significant.

Table 5: Relationship between the type of work and training experience and type of engaged/not engaged of physical activity in people aged 18-45 living in the county of Rzeszow

\begin{tabular}{|l|c|c|c|c|}
\hline Variable & Unemployed & $\begin{array}{c}\text { Sedentary } \\
\text { mode }\end{array}$ & $\begin{array}{c}\text { Standing } \\
\text { mode }\end{array}$ & $\begin{array}{c}\text { Pearson's chi } \\
\text { square p-value }\end{array}$ \\
\hline Training experience & & & & \\
[n; \%]: & $21 ; 37.50$ & $12 ; 48.00$ & $8 ; 15.69$ & \\
No training & $21 ; 37.50$ & $3 ; 12.00$ & $17 ; 33.33$ & $\mathbf{1 5 , 7 0 0 6}$ p $\mathbf{0 . 0 . 0 1}$ \\
Less than year & $7 ; 12.50$ & $4 ; 16.00$ & $12 ; 23.53$ & \\
1-2 years & $7 ; 12.50$ & $6 ; 24.00$ & $14 ; 27.45$ & \\
3-4 years & $0 ; 00.00$ & $0 ; 00.00$ & $0 ; 00.00$ & \\
More than year & & & & \\
\hline Type of engaged/not engaged & & & & \\
of physical activity [n; \%]: & $21 ; 37.50$ & $12 ; 48.00$ & $8 ; 15.69$ & \\
Not engaged & & & & \\
\hline
\end{tabular}




\begin{tabular}{|l|c|c|c|c|}
\hline \hline Gym (fitness, zumba, step etc.) & $23 ; 41.07$ & $13 ; 52.00$ & $43 ; 84.31$ & \\
Team sport games (soccer, & & & & \\
handball, volleyball etc.) & $12 ; 21.43$ & $0 ; 00.00$ & $0 ; 00.00$ & $\mathbf{3 1 , 8 8 0 8 ;} \mathbf{p = 0 . 0 0}$ \\
Swim & $0 ; 00.00$ & $0 ; 00.00$ & $0 ; 00.00$ & \\
Dance & $0 ; 00.00$ & $0 ; 00.00$ & $0 ; 00.00$ & \\
\hline
\end{tabular}

We found statistically significant relationships between a place of living and engaged/not engaged in physical activity and type of spending free time in people aged 18-45 living in the county of Rzeszow. The largest group of people who were engaged in physical activity were people living in rural-urban area $-90.48 \%$ of the study group. Over $50 \%$ of all respondents' state that they actively spend their free time. The data contained in the table 6 are statistically significant.

Table 6: Relationship between a place of living and engaged/not engaged in physical activity and type of spending free time in people aged 18-45 living in the county of Rzeszow

\begin{tabular}{|l|c|c|c|c|}
\hline Variable & City & $\begin{array}{c}\text { Rural } \\
\text { area }\end{array}$ & $\begin{array}{c}\text { Rural-urban } \\
\text { area }\end{array}$ & $\begin{array}{c}\text { Pearson's chi } \\
\text { square p-value }\end{array}$ \\
\hline $\begin{array}{l}\text { Engaged/not engaged } \\
\text { in physical activity [n; \%]: }\end{array}$ & & & & \\
$\begin{array}{l}\text { Yes } \\
\text { No }\end{array}$ & $25 ; 53.19$ & $28 ; 65.12$ & $38 ; 90.48$ & $\mathbf{1 4 , 8 3 4 6 ;} \mathbf{p = 0 . 0 0}$ \\
\hline $\begin{array}{l}\text { Spending free time [n; \%]: } \\
\text { Passive (e.g.: watching tv) }\end{array}$ & $22 ; 46.81$ & $15 ; 34.88$ & $4 ; 9.52$ & \\
$\begin{array}{l}\text { Active (e.g.: engaged physical } \\
\text { activity) }\end{array}$ & $25 ; 53.19$ & $28 ; 65.12$ & $38 ; 90.48$ & $\mathbf{1 4 , 8 3 4 6 ;} \mathbf{p = 0 . 0 0}$ \\
\hline
\end{tabular}

The data from Table 7 suggest statistically significant dependence between engaged/ not engaged in physical activity and paying attention to the proper diet. The Table 7 shows that respondents who did not engaged in physical activity more often consume unhealthy meals or snack (58.54\%) than people who were engaged in physical activity. There was no statistically significant difference between respondents who were engaged/not engaged in physical activity in the case of use stimulants.

Table 7: Relationship between engaged/ not engaged in physical activity and use stimulants and proper diet in people aged 18-45 living in the county of Rzeszow

\begin{tabular}{|c|c|c|c|}
\hline Variable & $\begin{array}{c}\text { Engaged in } \\
\text { physical activity }\end{array}$ & $\begin{array}{l}\text { Not engaged in } \\
\text { physical activity }\end{array}$ & $\begin{array}{c}\text { Pearson's chi } \\
\text { square p-value }\end{array}$ \\
\hline $\begin{array}{l}\text { Use stimulants [n; \%]: } \\
\text { Smoking } \\
\text { Drinking alcohol }\end{array}$ & $\begin{array}{l}62 ; 68.13 \\
29 ; 31.87\end{array}$ & $\begin{array}{l}29 ; 70.73 \\
12 ; 29.27\end{array}$ &, $089221 ; p=0.76$ \\
\hline $\begin{array}{l}\text { Paying attention to the proper } \\
\text { diet [n; \%]: } \\
\text { Yes, always } \\
\text { Yes, but sometimes I eat } \\
\text { unhealthy meals or snacks } \\
\text { No }\end{array}$ & $\begin{array}{l}31 ; 34.07 \\
26 ; 28.57 \\
34 ; 37.36\end{array}$ & $\begin{array}{c}9 ; 21.95 \\
24 ; 58.54 \\
8 ; 19.51\end{array}$ & 10,$8997 ; p=0.00$ \\
\hline
\end{tabular}


On the basis of the research included in the table 8 , it has been stated that there is a statistically significant relationship between factors motivated to engaged in physical activity and feel need to engage in physical activity and actually engaged or nor/engaged in physical activity in people aged 18-45 living in the county of Rzeszow. The data from Table 8 shows that people who did not engaged in physical activity in $58.54 \%$ claim that factors motivated to engaged in physical activity could be improvement physical condition and in $41.46 \%$ lose weight. Respondents who were engaged in physical activity in $70.33 \%$ declare that the main motivation to engaged in physical activity was a desire to discharge energy. The data contained in Table 8 show in detail the statistical relationships between the studied groups.

Table 8: Relationship between engaged/not engaged in physical activity and factors motivated to engaged in physical activity and feel need to engage in physical activity in people aged 18-45 living in the county of Rzeszow

\begin{tabular}{|l|c|c|c|}
\hline Variable & $\begin{array}{c}\text { Engaged in } \\
\text { physical activity }\end{array}$ & $\begin{array}{c}\text { Not engaged in } \\
\text { physical activity }\end{array}$ & $\begin{array}{c}\text { Pearson's chi } \\
\text { square p-value }\end{array}$ \\
\hline Factors motivated to engaged in & & & \\
physical activity [n; \%]: & & & \\
Improvement physical condition & $23 ; 25.27$ & $24 ; 58.54$ & \\
Lose weigh & $4 ; 4.40$ & $17 ; 41.46$ & $\mathbf{6 2 , 0 2 9 5 ; ~} \mathbf{p = 0 . 0 0}$ \\
Energy discharge & $64 ; 70.33$ & $0 ; 00.00$ & \\
Prove that I can overcome & $0 ; 00.00$ & $0 ; 00.00$ & \\
my weaknesses & & & \\
\hline Need to engage in physical & & & \\
activity [n; \%]: & $91 ; 100.00$ & $0 ; 00.00$ & $\mathbf{1 3 2 , 0 0 ;} \mathbf{p = 0 . 0 0}$ \\
Yes & $0 ; 00.00$ & $41 ; 100.00$ & \\
No & & &
\end{tabular}

\section{Discussion}

The results of various experimental studies show that health is one of the most important values appreciated by Poles. The very state of health of each person largely depends on the lifestyle of the individual, including their physical activity (Cleland 2013, Verweij 2011, McPhee 2016).

Physical activity of people of all ages is the top education. For solving problems related to exercise frequency and examining physical problems on health. As shown by the results of studies presented in numerous scientific publications on physical activity among the Polish society, a large number of respondents play sports or undertake other physical activity, some of which do it regularly, and some from time to time (Bruce 2008, Sweeting 2016). Physical activity is undertaken by people of all ages, both residents of cities and rural areas. The results of own research showed that as many as $38.99 \%$ of the surveyed women lived in a rural-urban commune, while $24.42 \%$ of women lived in the city. Among men, $38.36 \%$ of men live in the countryside, $35.62 \%$ in the city, while $26.02 \%$ of men live in rural and urban areas. Recreational sport is present more often in the lives 
of young people, educated and living in urban agglomerations. Cycling, swimming, jogging, walking, and gymnastics are popular. There are many reasons why people start sports activities, among others. taking care of health $(70 \%)$, pleasure $(61 \%)$, stress relief and relaxation (47\%) (Biernat 2011, Lindstrom 2000). A publication by Sallis and Glanz showed that adults living in cities, walking and cycling to get around, are more physically active. This is in contrast to those who live in the suburbs of cities and are dependent on car transport. Therefore, it is worth noting that regular physical activity, especially in old age, has a positive effect on the cardiovascular system, and thus positively affects the quality of life of seniors (Sallis 2009).

Among the surveyed inhabitants of the Podkarpackie Province, men much more often than women declare regular willingness to physical activity. This is confirmed by the phenomenon described quite often in scientific articles on sport (MakowiecDąbrowska 2012, Lindström 2001). In the case of the Podkarpackie population, it may result from the fact that the so-called traditional family model. The women do the housework and look after the children. Numerous household chores combined with professional work make women's leisure time very limited, which makes it difficult for them to carry out their own physical activities in their free time. It is worth noting that professional physical activity (hard physical work) is not always beneficial and may, for example, increase the risk of cardiovascular or movement diseases. In the article, Charzewski et al. and Nowak-Zaleska et al. performed univariate analyzes in groups of mature people. The authors proved that the gender of the respondents is the factor that differentiates physical activity in free time (men are more active). However, it is conditioned by several socioeconomic and demographic variables (age, sex, education, place of residence, marital status, income, work) (Charzewski 1997, Nowak - Zalewska 2011). Lindström et al. and expressed a different opinion. They proved that after considering gender as one of many variables in the multivariate analysis, it was not confirmed that it was significantly correlated with physical activity in free time (Lindström 2001, Oliveira 2014, Staiano 2013).

The conducted own research shows that $40.90 \%$ of the studied group lead an active lifestyle, $31.06 \%$ not very active, and only $28.04 \%$ lead a very active lifestyle. Among the respondents, the chances of achieving a minimum of physical activity decreased with age, which is confirmed by the results of studies obtained by other authors (Ignasiak 2013). In the publications of De Calvalho Mourão et al. describing multivariate analyzes of the majority of the population, the percentage of people inactive or insufficiently active in their free time increases with age (Calvalho Mourão 2013). However, other authors, i.e. Norman et al. or Chen et al. Confirm the increase in the number of people who are sufficiently active in their free time in older age groups (Norman 2002, Chen 2011). In the conducted own research among the inhabitants of Podkarpacie region, the vast majority of the studied group engages in physical activity $68.94 \%$, and the remaining part (31.06\% of the studied group) is not physically active. According to Nadobnik et al., polish society in Europe is considered not very active in physical activity (Nadobnik 2018). With age, the need for physical activity decreases, and 
the number of people who prefer passive rest increases. Also, young people more and more often show very low levels of physical activity and also choose to lead a passive inactive lifestyle. A study by Walid Kamal Abdelbasset et al. on the Egyptian population proved that groups with moderate and high physical activity had significantly higher HRQoL scores in all dimensions than groups with low physical activity. Chronic diseases prevailed in the low-level exercise group compared to the high and moderate exercise group. High and moderate levels of physical activity have been found to be very positively related to HRQoL among middle-aged and elderly adult communities in Egypt (Abdelbasset 2019).

The assessed dependence of the length of training internships and the nature of professional work showed that the amount of physical activity increased in people with the standing mode and they choose physical activity of a strength nature, including fitness, zumba and step. Non-working people are also willing to play team sports games as their physical activity. According to Misigoj-Durakonic et al. as well as Iwai et al., less educated people usually undertake greater physical effort at work, while higher education is associated with greater involvement in physical activity in their free time (Misigoj-Durakovic 2000, Iwai 2000). The research by Chinn et al. also showed that the most common barriers preventing well-educated people from taking up physical activity are motivation and lack of free time (Chinn 2000). Puciato et al. analyzed the professional status of respondents and concluded that more than half of the representatives of such professions as policemen, soldiers, teachers, scientists and operators, and 3/4 of bluecollar workers engage in habitual physical activity, which is in line with the recommendations of the ASCM (American College of Sports Medicine - ACSM) (Puciato 2012). On the other hand, among the respondents from other analyzed professional groups, the percentage of people undertaking physical exercise beneficial for health was much lower (Dtrong 2005).

It is obvious that the sphere of behavior related to the use of stimulants such as tobacco or alcohol is very important for human health. As described by researchers in publications, among others Dtrong et al. and Piotrowska et al. poor dietary habits in the family and problems with adapting young people to the environment mean that the problem of using stimulants increases in the early stages of life (Dtrong 2005, Piotrowska 2009, Corazza 2011). The substances disrupt the functioning of our body, cause many diseases and are addictive. However, nowadays the problem of the use of more serious stimulants, namely psychoactive substances, drugs and legal highs, is growing, as pointed out in the publication by Corazza et al. These substances, apart from their negative impact on the health of an individual, often lead to the development of the addiction syndrome (Corazza 2011, Siwiński 2015). The own research did not confirm the relationship between physical activity and the use of stimulants, there was only a statistically significant relationship between physical activity and a proper diet. On the other hand, there was a correlation among the respondents from the Podkarpackie Province between practicing physical activity and the factors motivating to undertake it. In their publication, Siwiński et al. emphasize the urgent need to implement the results 
of scientific research into everyday practice, showing the beneficial effects of regular physical exercise in the Polish population (Siwiński 2015).

The importance of the issues discussed in the article makes it necessary to conduct further research in this thematic area. This research should be continuous and take into account other methods and techniques of physical activity research and include interpersonal and environmental conditions. It is also justified to extend the spatial scope of the research to other areas of Poland so that it is possible to draw conclusions about the physical activity of the population in a broader manner.

\section{Conclusion}

The analysis of own research shows the following conclusions:

1. The own research showed a statistically significant dependence between sex and the number of trainings per week and duration of one training session.

2. Significant relationships also appeared between sex and training experience and type of physical activity in people aged 18-45 living in the county of Rzeszow.

3. The data obtained in the research work shows that there is a statistically significant relationships between the type of work and type of engaged/ not engaged of physical activity, numbers of training in a week and duration of the one training in people aged 18-45 living in the county of Rzeszow.

4. Own study showed there is a statistically significant relationship between people who are unemployed, sedentary mode work and standing mode work and training experience.

5. Own research proved that there is a relationship between a place of living and engaged/not engaged in physical activity and type of spending free time in people aged 18-45 living in the county of Rzeszow.

6. Based on the research results included in the research work, it follows that there is a statistically significant dependence between engaged/not engaged in physical activity and paying attention to the proper diet.

7. Our research proved that there is a relationship between engaged/not engaged in physical activity and factors motivated to engaged in physical activity and feel need to engage in physical activity in people aged 18-45 living in the county of Rzeszow.

\section{Conflicts of Interest}

The authors declare that there are no conflicts of interest regarding the publication of this article.

\section{About the Author(s)}

Doctor of Health Sciences Joanna Majewska, Medical College of Rzeszow University, Institute of Health Science, Poland. Research interests: injuries in sport, pediatrics, orthopedics, nutrition in sport, movement and training 
Master of Physiotherapy Gabriela Kołodziej-Lackorzyńska, Medical College of Rzeszow University, Institute of Health Science, Poland. Research interests: sport science, physical activity, nutrition and supplementation in sport, orthopedics and physical therapy in sport, injuries in sport, movement and training.

Master of Physiotherapy Barbara Cyran-Grzebyk, Medical College of Rzeszow University, Institute of Health Science, Poland. Research interests: injuries in sport, movement and training, orthopedic, pediatric, nutrition in sport, physical activity.

Doctor of Physical Education Krzysztof Kołodziej Medical College of Rzeszow University, Institute of Health Science, Poland. Research interest: physical activity, injuries in sport, ortopedisc and neurology movement and training.

Doctor of Physical Education Robert Czaja Institute of Physical Culture Studies, College of Medical Sciences, University of Rzeszów. Research interest: physical activity, health, functional fitness, movement and training

Master of Physical Education Kamil Sałagaj Institute of Physical Culture Studies, College of Medical Sciences, University of Rzeszów. Research interest: physical activity, physical fitness, movement, training.

\section{References}

Abdelbasset WK, Tantawy SA, Kamel DM, Alqahtani BA, Soliman GS, 2019. A randomized controlled trial on the effectiveness of 8-week high-intensity interval exercise on intrahepatic triglycerides, visceral. lipids, and health-related quality of life in diabetic obese patients with nonalcoholic fatty liver disease, Medicine (Baltimore), 98(12):e14918.

American Heart Association recommendations for physical activity in adults [website]. Dallas (TC): American Heart Association; 2014 (http://www.heart.org/HEARTORG/GettingHealthy/PhysicalActivity/FitnessBasi cs/America-Heart-Association-Recommendations-for-Physical-Activity-inAdults UCM 307976 Article.jsp, accessed 14 February 2021).

Amorim TC, Azevedo MR, Hallal PC, 2010. Physical activity levels according to physical and social environmental factors in a sample of adults living in South Brazil, Journal of Physical Activity and Health, Jul;7 Suppl 2:4-12.

An KY, 2017. Physical activity level in Korean adults: the Korea National Health and Nutrition Examination Survey, Epidemiology and Health, 41:2019047.

Barber FD, 2013. Effects of social support on physical activity, self-efficacy, and quality of life in adult cancer survivors and their caregivers, Oncology Nursing Forum, 40(5):481-489.

Bauman AE, Reis RS, Sallis JF, Wells JC, Loos RJF, Martin BW, 2012. Correlates of physical activity: why are some people physically active and others not? Lancet, 21;380(9838):258-271. 
Bidzan-Bluma I, Lipowska M, 2018. Physical Activity and Cognitive Functioning of Children: A Systematic Review, International Journal of Environmental Research and Public Health, 19;15(4):800.

Biernat E., Tomaszewski P, 2011.Socio-demographic and leisure activity determinants of physical activity of working Warsaw residents aged 60 to 69 years, Human Kinetics, 30(4):173-181.

Boniecka K, 2018. Aktywność fizyczna, zachowania żywieniowe i ocena ciała u dziewcząt w drugiej fazie dorastania, Przegląd Pedagogiczny 2:170-179.

Bruce B, Fries JF, Hubert H, 2008. Regular vigorous physical activity and disability development in healthy overweight and normal-weight seniors: a 13-year study, American Journal of Public Health, 98:1294-1299.

Charzewski J, 1997. Aktywność sportowa Polaków. Sport activity of the Polish people. Warszawa: Akademia Wychowania Fizycznego Warszawa.

Chen YJ, Huang YH, Lu FM, Wu Js, Lin LL, Chang ChJ, 2011. The correlates of leisuretime physical activity among adults' population from Southern Taiwan, BMC Public Health, 11(1): 427-435.

Chinn DJ, White M, Harland J, Drinkwater C, Raybould S, 1999. Barriers to physical activity and socioeconomic position: implications for health promotion, Journal of Epidemiology and Community Health, 53:191-192.

Cleland V, Ball K, Crawford D, 2012.Socioeconomic position and physical activity among women in Melbourne, Australia: Does the use of different socioeconomic indicators matter? Social Science and Medicine,74(10):1578-1583.

Corazza O, Schifano F, Farre M, et al. 2011. Designer Drugs on the Internet: a Phenomenon Out-of-Control? The Emergence of Hallucinogenic Drug BromoDragonfly. Current Clinical Pharmacology, 6(2): 125-129.

Corazza O, Schifano F, Simonato P, et al, 2011. The phenomenon of new drugs on the Internet: a study on the diffusion of the ketamine derivative methoxetamine, Human Psychopharmacology, 27: 145-149.

de Calvalho Mourão AR, Novais FV, Andreoni S, Ramos LR, 2013. Physical activity in the older adults related to commuting and leisure, Maceió, Brazil. Revista de Saúde Pública, 47(6): 1112-1122.

Ding D, Lawson KD, Kolbe-Alexander TL, Finkelstein EA, Katzmarzyk PT, Mechelen W, et al, 2016. The economic burden of physical inactivity: a global analysis of major non-communicable diseases, 24;388:1311-1324.

European Commission. Special Eurobarometer 412-Sport and Physical Activity. Available online: https://ec.europa.eu/commfrontoffice/publicopinion/archives/eb special 419400 en.htm\#412 (accessed on 14 February 2021).

European Commission. Special Eurobarometer 412-Sport and Physical Activity. Available online: https://ec. europa.eu/commfrontoffice/publicopinion/archives/eb special 419400 en.htm\# $\underline{412}$ (accessed on 14 February 2021). 
European Commission. Special Eurobarometer 472-Sport and Physical Activity. Available online: https://ec.europa.eu/sport/news/2018/new-eurobarometersport-and-physical-activity en (accessed on 14 February 2021).

Fredriksson SV, Alley SJ, Rebar AL, Hayman M, Vandelanotte C, Schoeppe S, 2018. How are different levels of knowledge about physical activity associated with physical activity behaviour in Australian adults? PLoS ONE, 13(11): e0207003,

Gablankowska M, Radziszewska S, 2019. Aktywność fizyczna kobiet w ciąży, w trakcie porodu oraz połogu. Sztuka leczenia 1: 59-64.

Global recommendations on physical activity for health. Geneva: World Health Organization;

(http://whqlibdoc.who.int/publications/2010/9789241599979 eng.pdf, accessed 14 Februar 2021).

Ignasiak Z, Sławińska T., Dąbrowski A, Rowiński R, 2013. The structure of physical activity in seniors from lower Silesia. Roczniki Państwowego Zakładu Higieny, 64(1):67-73.

Iwai N, Yoshiike N, Saitoh S, Nose T, Kushiro T, Tanaka H, 2000. Leisure-time physical activity and related lifestyle characteristics among middle-aged Japanese, Journal of Epidemiology, 10:226-233.

Sweeting J, Ingles J, Timperio A, Patterson J, Ball K, Semsarian C, 2016. Physical activity in hypertrophic cardiomyopathy: prevalence of inactivity and perceived barriers, Open Heart, 20;3(2):e000484.

Kantomaa MT, Tikanmäki M, Kankaanpää A, Vääräsmäki M, Sipola-Leppänen $M$, Ekelund U, et al. 2016. Accelerometer-Measured Physical Activity and Sedentary Time Differ According to Education Level in Young Adults. PLoS ONE. 11(7): e0158902.

Kubińska Z, Pańczuk A, 2018. Potrzeby zdrowotne realizowane przez aktywność fizyczną osób starszych. Rozprawy Społeczne 12; 1:73-79.

Lee IM, Shiroma EJ, Lobelo F, Puska P, Blair SN, Katzmarzyk PT, 2012. Lancet physical activity series working group: effect of physical inactivity on major noncommunicable diseases worldwide: an analysis of burden of disease and life expectancy, Lancet, 380:219-29.

Lindström M, Hanson B, Ostergren P., Berglund G, 2000. Socioeconomic differences in smoking cessation: The role of social participation, Scandinavian Journal of Public Health, 28:200-208.

Lindström M, Hanson BS, Östergren PO, 2001. Socioeconomic differences in leisure-time physical activity: the role of social participation and social capital in shaping health related behaviour, Social science and Medicine, 28:200-208.

Makowiec-Dąbrowska T, 2012. The influence of physical activity at work and in everyday life on the circulatory system. Forum Medycyny Rodzinnej, 6 (3): 130-138.

McPhee JS, French DP, Jackson D, Nazroo J, Pendleton N, Degens H, 2016. Physical activity in older age: perspectives for healthy ageing and frailty, Biogerontology, 17(3):567-580. . 
Misigoj-Durakovic M, Heimer S, Matkovic B, Ruzic L, Prskalo I, 2000. Physical activity of an urban adult population: questionnaire study, Croatian Medical Journal, 41:428432.

Molanorouzi, K, Khoo, S and Morris, T, 2015. Motives for adult participation in physical activity: type of activity, age, and gender. BMC Public Health, 15:66.

Nadobnik J, 2018. Selected determinants accompanying the formation non-governmental organizations operating in Poland in the sectors of tourism, recreation, sport and hobby in the years 2006-2017. Zeszyty Naukowe Turystyka i Rekreacja, Zeszyt 22 (2): 19-38. Red. Naczelny halina Makała, Wyższa Szkoła Turystyki i Języków Obcych, Warszawa.

Norman A, Bellacco R, Vaida F, Wolk A, 2002. Total physical activity in relation to age, body mass, health and other factors in a cohort of Swedish men, International Journal of Obesity and Related Metabolic Disorders, 26(5): 670-675.

Nowak - Zaleska A, 2011.Candidates for the First Year of Studies at the University Level Institution of Physical Education and Their Physical Activity, DOI: 10.2478/bjha2013-0008.

Oliveira AJ, Lopes CS, Rostila M, Werneck GL, Griep RH, Ponce de Leon ACM, Faerstein E, 2014. Gender differences in social support and leisure-time physical activity, Revista de Saúde Pública, 48(4):602-612.

Physical activity, https://www.who.int/news-room/fact-sheets/detail/physical-activity. Accessed 14 Februar 2021.

Piotrowska E, Zechałko-Czajkowska A, Biernat J, Mikołajczak J, 2009. Assessment of selected features of the lifestyle being conduicive to the state of health of 16-18 year old girls. Part I. Dieting, physical activity, smoking and drinking alcohol. Roczniki Panstwowego Zakladu Higieny, 60(1):51-57.

Puciato D, Rozpara M, Mynarski W, Łoś A, Królikowska B, 2013. Physical activity of adult residents of Katowice and selected determinants of their occupational status and socio-economic characteristics, Medycyna Pracy 64(5):649-657.

Puszczałowska Lizis- E, Kuźniar K, Bać K, i wsp., 2017. Aktywność fizyczna i niektóre jej uwarunkowania w populacji seniorów województwa podkarpackiego. Zamojskie Studia i Materiały. Tom XIX;1: 7-17.

Rozek-Piechura, K, Ignasiak, Z, Sławinska, T, Piechura, R; Ignasiak, T, 2014. Respiratory function. physical activity and body composition in adult rural population, Annals of Agricultural and Environmental Medicine, 21(2):369-374.

Sallis JF, Glanz K, 2009. Physical Activity and Food Environments: Solutions to the obesity epidemic, Milbank Quarterly, 87(1):123-154.

Sallis JF, Bull F, Guthold R, Heath GW, Inoue S, Kelly P, et al, 2016. Progress in physical activity over the Olympic quadrennium, Lancet, 24;388(10051):1325-1336.

Siwiński W, Rasińska R, 2015. Physical activity as essential objective of lifestyle and human health. Pielęgniarstwo Polskie, 2, (56):181-188. 
Staiano AE, Harrington DM, Barreira TV, Katzmarzyk PT, 2014. Sitting time and cardiometabolic risk in US adults: associations by sex, race, socioeconomic status and activity level, British Journal of Sports Medicine, 48(3):213-219.

Strong WB, Malina RM, Blimkie CJ, Daniels SR, Dishman RK, Gutin B, Hergenroeder AC, Must A, Nixon PA, Pivarnik JM, Rowland T, Trost S, Trudeau F, 2005. Evidence based physical activity for school-age youth, Journal of Pediatrics, 146(6):732-7.

Verweij LM, Coffeng J, van Mechelen W, Proper KI, 2011. Meta analysis of workplace physical activity and dietary behavior interventions on weight outcomes, Obesity Reviews, 12:406-429.

Warchol K, Korobeynikov G, Osiel C, Cynarski WJ, 2021. Martial arts as a form of physical activity for children and young people in the opinion of adult inhabitants of Podkarpackie Voivodeship. Ido Movement for Culture, 21;1: 28-37.

Wołoszyn N, Wiśniowska-Szurlej A, Sozański B, 2018. An assessment of the relationship between the level of physical activity and the risk of falls and depression in elderly adults aged 60 - 75 years from the Podkarpackie region, Advances i Rehabilitation, 32;2:41-48.

World Health Organization. Global action plan for the prevention and control of noncommunicable diseases 2013-2020; 2013 [cited 2021 Feb 14]. Available from: https://www.who.int/nmh/publications/ncd-action-plan/en/.

Zawadzka D, Mazur J, Oblacińska A, 2015. Samoocena sprawności fizycznej i witalności a aktywność fizyczna młodzieży szkolnej, Problemy Higieny i Epidemiologii 96 (1): 149-156. 
Authors will retain the copyright of their published articles agreeing that a Creative Commons Attribution 4.0 International License (CC BY 4.0) terms will be applied to their work. Under the terms of this license, no permission is required from the author(s) or publisher for members of the community to copy, distribute, transmit or adapt the article content, providing a proper, prominent and unambiguous attribution to the authors in a manner that makes clear that the materials are being reused under permission of a Creative Commons License. Views, opinions and conclusions expressed in this research article are views, opinions and conclusions of the author(s). Open Access Publishing Group and European Journal of Physical Education and Sport Science shall not be responsible or answerable for any loss, damage or liability caused in relation to/arising out of conflict of interests, copyright violations and inappropriate or inaccurate use of any kind content related or integrated on the research work. All the published works are meeting the Open Access Publishing requirements and can be freely accessed, shared, modified, distributed and used in educational, commercial and non-commercial purposes under a Creative Commons attribution 4.0 International License (CC BY 4.0). 